\title{
CONSUL GABRIELA MISTRAL IN PORTUGAL, 1935-1937: "UN POLICÍA EN LA ESQUINA Y DOS O TRES ESPÍAS ADENTRO DEL HOTEL"
}

\begin{abstract}
RESUMEN
Portugal marca un punto de inflexión en la carrera literaria y consular de Gabriela Mistral. Su convalecencia en Lisboa se vio transformada por el estallido de la Guerra Civil española. Trabajó para evacuar académicos, artistas, y médicos. Cuando las autoridades chilenas buscaron trasladarla, sus amigos le facilitaron invitaciones de Ginebra y París, algo que le permitió seguir colaborando en el trabajo humanitario desde Portugal, donde consiguió una reorientación hacia América y una proyección mayor desde el reconocimiento europeo, que amplió la visibilidad de su trabajo y figura. Un análisis cuidadoso de sus acciones desde Lisboa revela el impacto que estas tuvieron más allá de su propia vida, a través de los emigrantes que contribuyeron a universidades y a otras instituciones en México, EE.UU. y Argentina. La identificación y secuenciación de sus escritos revela cómo ella fracasó y se recuperó del revés de sus dos primeras misiones consulares.
\end{abstract}

Palabras clave: Gabriela Mistral, correspondencia literaria y diplomática, biografía, Guerra Civil española, Portugal, Chile, México.

\section{ABSTRACT}

Portugal is a turning point in Gabriela Mistral's consular and literary careers ${ }^{1}$. Her convalescence in Lisbon was transformed by the outbreak of the Spanish Civil War, as she worked to evacuate endangered Spanish academics, artists, and doctors. When Chilean authorities sought her transfer, her friends issued a storm of

* Doctora en Literatura. Arizona State University, Tempe. Correo electrónico: elizabeth.horan@asu.edu

1 For encouragement and access to archives, I extend my deepest thanks to Doris Atkinson. Georgette Dorn of the Hispanic Reading Room and the staff of the Manuscript Reading Room of the U.S. Library of Congress let me consult, in opportune moments, the microfilms on which much of this work is based. Deep thanks likewise to Nivea Palma of the Biblioteca Nacional de Chile, and Pedro Pablo Zegers, Tomás Harris, and the staff of the Archivo del Escritor of the Biblioteca Nacional de Chile, where the originals of the Dana Atkinson archives now reside. Luis Vargas Saavedra has been a patient and generous interlocutor, whose work on Gabriela Mistral in Spain pointed the way. Cassandra Swick helped with final revisions. I am grateful to the English Department Personnel Committee and English Department Chair Neal Lester at Arizona State University granted the senior leave from teaching in Spring 2009 that let me revise an earlier draft of this research, which editors of Anales de Literatura Chilena published in a Spanish-language version, translated by Eduardo Muslip: see Elizabeth Horan, "Una Mixtura de Calvario y Arcadia", en Anales de Literatura Chilena 10:11, Santiago, junio de 2009, 13-43. 
invitations from Geneva and Paris, which enabled her to continue contributing to humanitarian relief from Portugal, where she reoriented her interests towards America and increased her work's visibility by obtaining recognition in Europe. Careful study of her actions from Lisbon reveals their impact, which extended past her own life: the emigrants whom she helped contributed to universities and other institutions in Mexico, the U.S., and Argentina. Uncovering these actions comes from engaging in an accurate identification and sequencing of her published and unpublished writings, which reveals how she failed and recovered from her first two consular assignments.

Key words: Gabriela Mistral, Correspondence: Literary and Diplomatic, Biography, Spanish Civil War, Portugal, Chile, Mexico.

Fecha de recepción: marzo de 2009

Fecha de aceptación: junio de 2009

\section{INTRODUCTION}

Much is known of Gabriela Mistral's infelicitous transfer from Madrid, "uno de los episodios más deplorables en la historia diplomática chilena provocado por un desliz imperdonable de la escritora" . "Su brusco traslado a Lisboa debe haberle parecido un catástrofe [...]"3, "de su permanencia en Portugal poco se sabe"4. Mistral was living in Lisbon when she received the following anonymous, insulting letter, which included a paragraph that gleefully summarized and underscored her failures:

"De Italia la echaron violentamente. De España, grandísima farsante, salió Ud. con un contundente puntapié en las nalgas. Cuídese en su nueva residencia. Aunque lo veo difícil, la traición, la falta de nobleza la lleva Ud. retratada en su cara. Esta es el espejo del alma. Cuídese, y que se alivie de su hidrofobia. No merece Ud., ni el escupitajo que desde aquí le envío"5.

Gabriela Mistral's actions in Portugal, which were founded on the difficult start of her consular career, can be understood in the context of her internationallysignificant intellectual and political allegiances. The beginnings of her reversed fortunes appear in a series of three surprising events, which grew from her response, in conjunction with her intellectual peers beyond Chile, to the Spanish Civil War. First, within a year of when she was sent from Madrid in order to avoid Spain's declaring her persona non grata, easily the nadir of her consular career,

2 Ana Caballé, "Gabriela Mistral en Madrid", en Anales de la literatura hispanoamericana 22, Madrid, 1993, 240.

3 Tan de Usted. Epistolario de Gabriela Mistral con Alfonso Reyes, Ed. Luis Vargas Saavedra, Santiago, Hachette/Ediciones Universidad Católica de Chile, 1990, 39.

4 Luis Vargas Saavedra, Castilla tajeada de sed como mi lengua. Gabriela Mistral ante España y España ante Gabriela Mistral 1933-1935, Santiago, Universidad Católica de Chile, 2002, 221.

5 "Xan de Cirollas", letter to Gabriela Mistral, prob.Oct-Nov. 1935, Dana Atkinson Archive. 
Chile's Ministerio de Relaciones Exteriores reversed course. Without requiring her to change residence or adding to her official duties, she was named to the post of Consul to Oporto and to another two consular posts, which she had not sought, although she was pleased, for the appointments brought her a substantial increase in her pay. As a study of her actions in Portugal and thereafter shows, Chilean authorities (who backed the Nationalists in Spain) hoped that she would transfer her field of operations to Latin America. She responded, working through friends, to bring about a second set of events: Paris and Geneva began showering her with invitations. This had the effect of stalling her departure from Europe, and enhancing her contacts with like-minded pro-Republic, anti-communist and antifascist intellectuals in France and Germany. In all, by 1937, the second-class consul had effectively become Chile's highest-ranking representative in Portugal. As opposed to the conservative, pro-Nationalist diplomats who represented Chile in Madrid and London, Mistral used her situation in Lisbon to assist noncommunist supporters of the Spanish Republic.

The origins of Mistral's remarkable reversal of fortunes could be traced to the important allegiances that she formed in Lisbon, yet much of her effectiveness owed to long-term behaviors, a combination of personal qualities and habits that she'd developed in the course of her previous career as an itinerant educator. She befriended local and visiting writers and maintained correspondence with distant superiors. Working autonomously to serve the diverging interests of her superiors, she managed to placate figures both to the right and to the left. When she came to a new post, she scouted out her pre-eminent local rival and identified her next likely opportunity, for working as a journalist had taught her the importance of keeping in touch with her far-flung friends. Living in Salazar's Portugal, where her actions were routinely watched, she drew from her experience as an educator and journalist. She knew how to recognize and deal with spies.

Beyond character or habit, Gabriela Mistral's contemporaneous response to the Spanish Civil War reveals a little-appreciated but defining aspect of her biography: she persistently sought out and resided in conflict zones. The generally fragmentary, hagiographic and nationalistically-motivated approaches to her figure have failed to acknowledge or account for her repeated decision to live in or near situations of war or conflict. Such enterprise gave her the ability to overcome the odds against her as one of the very few women in the consular corps, and thus to move up within the hierarchy. War and other forms of conflict gave her the opportunity to gather human intelligence, which she passed along to interested, but distant political figures, generally (but not always) liberal or radical politicians. Although she'd honed her skills in Chile, gathering and relaying information amid violently repressed strikes in Punta Arenas and a hotly contested election campaign in Temuco and Santiago, the poet's allegiances with respect to the Spanish Civil War grew from her contacts with Mexican, Colombian, and Argentine intellectuals, moderate non-communist, anti-fascist leftists. Working with Alfonso Reyes, Palma Guillén, and Daniel Cosío Villegas, who openly and actively supported the Spanish Republic, proved crucial to Mistral's actions and ideological orientation in wartime Portugal. 
As Mistral rarely spoke of her activities in wartime Portugal, the poet's biographers, who tend to draw heavily and uncritically from the poet's own versions of her life story, have passed over this period in silence. "De su permanencia en Portugal poco se sabe", indicates Luis Vargas Saavedra. Addressing that gap in knowledge will fill out more of the ideological basis for her actions during a time that historians of Europe and the Americas have characterized as "one of the most critical events of the political history of the $20^{\text {th }}$ century". Mistral's allegiances led her to regard the war in somewhat different light than did writers who were further to the left than she was. What Western democratic countries tended to see as an encounter between democracy and fascism, and what writers such as her friend and colleague Neruda viewed as heralding a possible extension of a worker's revolution of Russia, Gabriela Mistral saw as a battle to the death between Spaniards, to the disadvantage of Catalans and Basques. Mistral's response emerged, then, from a combination of her contacts with Mexico, who sympathized with the Republic, and her friendships with intellectuals whose lives and livelihoods were in danger because of their identifications with regional interests in Cataluña, the Basque country, and (to a lesser extent) Galicia ${ }^{7}$.

\section{NAPles, Nov. 1932 - MAdRID, Nov. 1934: “CUALQUIER CONSUlADO”, OR HOW NOT TO BEGIN A CONSULAR CAREER}

Four years before Franco led an army revolt from Morocco to Spain, Gabriela Mistral entered the consular service of Chile at the very bottom of the scale. Her patron of the time, Pedro Aguirre Cerda, frankly described her first post, in Naples, as "un nombramiento que siquiera puede servir de base para solicitar después un ascenso" 8 . Although the poet performed all the necessary actions, the Italian government declined to accept her credentials. She was uncharacteristically terse in writing to lower-level bureaucrats in Santiago, describing why she'd been rejected: "El Gobierno italiano no acepta mujeres en esos cargos", she explained". Only in writing to her two most powerful protectors at the time, the Radical

6 Mark Falcoff and Frederick B. Pike (eds.), The Spanish Civil War 1936-1939: American Hemispheric Perspectives, Lincoln, University of Nebraska Press, 1982, ix.

7 The historiography of the Spanish Civil War is immense. Historians such as Gabriel Jackson, Ian Gibson, and Hugh Thomas vary on whether writers and intellectuals really played a major role in the conflict, yet they agree that the war produced major changes in the relation between intellectuals and the Spanish state. Following the work of Paul Preston, The Splintering of Spain: Cultural History and the Spanish Civil War 1936-1939, Cambridge, Cambridge University Press, 2005, includes many essays and an excellent introductory chapter by Chris Ealham and Michael Richards, who convincingly argue that only with the opening up of regional archives in the post-Franco era have historians begun to piece together the extent to which intellectuals' responses to the war varied according to local as opposed to centrist politics.

8 Pedro Aguirre Cerda, letter to Lucila Godoy, 12 May 1932, Archivo del Escritor, 2, 88.

9 Gabriela Mistral, letter to Raúl Silva Castro, 29 Sept. [1932], Archivo del Escritor, 5, 408; Gabriela Mistral a Max Salas Marchán, 1 Nov. 1932, Archivo del Escritor, 47. 
politician Pedro Aguirre Cerda of Chile and the Liberal Eduardo Santos of Colombia, did Mistral provide a fuller account. One factor was Chile's governmental instability at the time, while another was her continuing antifascist stance, which she'd developed following her work in Mexico, and had articulated on arriving in Italy in 1924, in a trip underwritten by the Mexican government ${ }^{10}$.

Still another factor in Mistral's uncharacteristic silence about her rejection in Naples could have stemmed from a desire not to bring attention to aspects of the situation which she had managed turn to her advantage, thanks in part to friends and contacts in Barcelona, Málaga, and Naples' diplomatic and consular communities. They helped Mistral to legalize her guardianship (shared with Palma Guillén) of her seven-year-old nephew, Juan Miguel Godoy. The two women left Naples with Juan Miguel as soon as they'd completed the paperwork that established the boy's dual Chilean and Spanish citizenship. The three headed north to Liguria, where they placed the boy with a teacher/governess. Palma continued on to join their mutual friends in Barcelona, while the poet stayed behind, where she had befriended Carlos Errázuriz, whose position within Chile's Ministry of Foreign Relations and political affiliations with conservatives would prove an unforeseen boon to the poet, over the next decade.

Mistral made her way to Iberia by the circuitous route of having been rejected from Mussolini's Italy, followed by a Christmas holiday spent with Catalan nationalists in Barcelona, capped off by a highly publicized, positive reception in Puerto Rico. She roamed the island, giving talks, attending receptions, and teaching classes at the University. Although Puerto Rico's legislature was "horriblemente divididos entre patriotas y ayancados", a bipartisan group came together to create for her "una ley especial por las dos Cámaras"11. As she happily informed Pedro Aguirre Cerda, the legislature declared her to be "hija adoptiva de país [...]"12. The recognition of honorary dual citizenship, which reflected her ability to mediate between warring parties, gave Pedro Aguirre and Carlos Errázuriz further arguments to convince Chile's new Minister of Relaciones Exteriores, Miguel Cruchaga Tocornal, that the poet merited at least an honorary consulate in Madrid.

10 Gabriela Mistral, letter to Eduardo Santos, 1 Oct. 1932, in Otto Morales Benítez (ed.), Gabriela Mistral: su prosa y poesía en Colombia, Bogotá, Convenio Andrés Bello, 2003, 2 vols.; and Gabriela Mistral (signing as "Lucila Godoy"), letter to Pedro Aguirre Cerda, 3 Nov. 1932, Archivo del Escritor, 2, 92 .

11 Gabriela Mistral, letter to Teresa de la Parra and Lydia Cabrera, in Cartas a Lydia Cabrera: Correspondencia inédita de Gabriela Mistral y Teresa de la Parra, Rosario Hiriart (ed.), Madrid, Torremozas, 1988, 207.

12 Gabriela Mistral (signing as "Lucila Godoy"), letter to Pedro Aguirre Cerda, 10 April 1933 [sic: 1934], in Gabriela Mistral, Antología Mayor III: Cartas, Luis Alberto Ganderats and Luis Vargas Saavedra (eds.), Santiago, Cochrane, 1992, 204. Excerpts from this same letter appear in Gabriela Mistral: Escritos Políticos, Jaime Quezada (ed.), México y Santiago, Fondo de Cultura Económica, 1994, 102-104, but with the correct year indicated (ibid., 137). I have used "sic" where the year as printed in Antología Mayor III: Cartas is contradicted by a proponderance of reliable internal evidence in combination with verifiably dated external sources. Antología Mayor III: Cartas remains an invaluable, pioneering text despite its flaws. 
The post to Madrid was a poor one, and poet correctly foresaw that her expenses would be high ${ }^{13}$. In lieu of a salary, she was to have received commissions from the payment of fees on passports and visas, whose value she overestimated, in her initial calculations. She also had misgivings about the harsh winter. Yet she accepted the nomination, probably from a combination of desire to ascend the ladder in the consular corps, and curiosity about Spain's new-found position as a leader of reform within Western Europe.

Newspaper polemic greeted her arrival in Madrid: Teresa de Escoriaza, a Basque writer more often based in New York, inveighed against her appointment ${ }^{14}$. A representative headline: "Duplica a una consulesa. Gabriela Mistral, o la crueldad araucana"15. Following the advice of Chile's Consul General in Barcelona $^{16}$, the new honorary consul was cautious, and downplayed the incident in her response to the press. She was quickly enveloped in straightening out the offices, which her predecessor and old acquaintance, the poet Victor Domingo Silva, had left in a welter of miscellaneous papers and unpaid bills. "Recibí este Consulado hecho una batahola de desorden y desidia [...] El pobre Silva, hasta hoy romántico y bohemio, dejó correr el agua, y nunca tuvo una oficina servida. Cuestión no de incapacidad sino de pereza"17. To take over the office, she had to absorb some of her predecessor's debts. New declines in the dollar decreased the value of what she'd saved from her teaching stints in the United States and Puerto Rico. Her financial picture worsened. The new consul's fears of cold weather were fulfilled as even the Southern areas of Spain froze over, during her first full winter in Madrid. "Había nieve en Cartagena por la primera vez en lustros"18.

Casting a pall over everything was Spain's electoral swing to the right, which occurred within months of Gabriela Mistral's arrival. As Caballé explains, the new consul's residence in Madrid precisely spanned the "bienio negro" of Spain's Second Republic, a low point in Spanish politics that began with Azaña's fall in October of 1933, and led into the dismissal of the Cortes two months after she'd left. "La crispación de la masa social -bien intuida por la escritora- fue en aumento [...] Nada era propicio"19. Gabriela Mistral's one hope for a change in her personal situation came when Pablo Neruda, fifteen years younger than Mistral, was appointed consul in Barcelona in mid-1934. She preferred Barcelona, where

13 On the poet's well-founded concern that she would face financial difficulty in Madrid, see Mistral, letter to Pedro Aguirre Cerda, 10 April 1933, op. cit., 206; Gabriela Mistral (signing as "Lucila Godoy"), letter to Pedro Aguirre Cerda, 10 June 1933 [sic: 1930], in ibid., 184-185. A valuable, detailed survey of these letters and the relationship of Gabriela Mistral to Pedro Aguirre Cerda appears in Matías Tagle Domínguez, "Gabriela Mistral y Pedro Aguirre Cerda a través de su correspondencia privada (1919-1941)", Historia 35, Santiago, 2002, 323-408.

14 On Teresa de Escoriaza, see Marta Palenque, "Ni Ofelias ni Amazonas, sino seres completos: aproximación a Teresa de Escoriaza", in Arbor, Madrid, 182:719, 2006, 363-376.

15 Vargas Saavedra, op. cit., 115.

16 Consul General: Armando Moock, letter to Gabriela Mistral, 3 Aug. 1933, Gabriela Mistral Collection, Library of Congress Microfilms.

17 Gabriela Mistral, letter to Armando Donoso, 10 Aug. 1933, Archivo del Escritor, 5, 410.

18 Carmen Conde, letter to Gabriela Mistral, 12 Feb. 1934, Gabriela Mistral Collection, Library of Congress microfilms.

19 Caballé, op . cit., 240. 
she had friends well-entrenched in the regional government, whereas Neruda's whole horizon was Madrid, with its late-night tertulias, male-dominated cafés and swanky Embassy parties, areas where Mistral didn't shine. As each poet had what the other wanted, Mistral and Neruda developed a plan to swap jobs, which Neruda explained to a friend: "Ella se dirige a Barcelona dando grandes saltos y yo permanezco de cónsul en Madrid, llorando a gritos de alegría como un verdadero centapiés"20. Gabriela Mistral was frank in telling Pedro Aguirre Cerda that she was tired of her unsalaried position as an honorary consul, which she described as a "cargo subalterno y con sueldo insuficiente". She wanted "un Consulado de carrera, aunque sea de última clase" 21 .

Mistral's difficulty in obtaining a transfer or promotion can be traced, at least in part, to her differences from her Chilean diplomatic and consular colleagues in Madrid. Her diplomatic colleague Carlos Morla Lynch relates her discomfort in an Embassy party. His description suggests, obliquely, that her difficulties in Madrid were compounded of being a single woman in her early 40 s with no independent income, and that she startled people with the informality of her mannerisms, her tendency to take offense, and her inclination to wax poetic about how she'd like to be eating fruit on a tropical island, rather than living in Madrid. She was, Morla insinuated, more than passing strange, a downright oddity among the elegant women and courtly men 22 . Barcelona would have been far more comfortable, presenting a wider, less aristocratic horizon, a milder climate, and a circle of intellectual friends, people with whom she had received earlier, warm welcomes. As Madrid grew more tense after the violent repressions of striking miners in Asturias in October of 1934, Mistral grew more anxious to depart: "Nunca he tenido mi vida más indecisa"23.

As it turned out, Santiago refused Mistral's petition to transfer to Barcelona, while Neruda's rank and well-situated friends enabled him to move to Madrid by August of 1934 without having to swap jobs with Mistral. While the poet from Temuco got a "decorative" job at the Embassy, Mistral remained, trapped in the Spanish capital ${ }^{24}$. Her nerves frayed as she churned out journalism to support herself, the consulate, and her young nephew Juan Miguel. Her savings vanished with the fall of the dollar, her rising expenses, and her eternally profligate halfsister Emelina continued to incur debts that Gabriela wound up having to

20 Pablo Neruda, letter to "Mujer Rubia" (Sara Tornú), 19 Sept. 1934, in Pablo Neruda, Epistolario viejero 1927-1973, Abraham Quezada Vergara (ed.), Santiago, RIL Editores, 2004, 97.

21 Gabriela Mistral, letter to Pedro Aguirre Cerda, 12 Oct. 1934, Archivo del Escritor, 95.

22 Carlos Morla Lynch, En España con Federico Garcia Lorca: Páginas de un diario íntimo 19281936, Madrid, Aguilar, 1957: this personal diary, published in very limited form under the censorship of the Franco regime, should be reissued in unexpurgated form, or otherwise made available to scholars. The manuscript version almost certainly contains information that would crucially contribute to the wider knowledge of the wide circle of Latin American and Spanish intellectuals who frequented the Chilean Minister's residence in Madrid in the years leading up to and including the Spanish Civil War.

23 Vargas Saavedra, op. cit., 208; Gabriela Mistral, letter to G. Zaldumbide, Oct. 1934, in Morales, op . cit.

24 Edmundo Olivares Briones, Pablo Neruda: Los Caminos del Mundo, Santiago, Lom Ediciones, 2001, 128. 
discharge 25 . The only prospect of relief came from Portugal, where the government invited Gabriela Mistral and Palma Guillén to join a group of intellectuals in a visit just prior to Christmas of $1934^{26}$.

\section{DEC. 1934-OCT. 1935: TWO VISITS TO LISBON}

As reflected in two "recados" that Gabriela Mistral wrote shortly after her first visit to Portugal, consular work and the atmosphere in Spain, along with the opportunity for a vacation from both of these, found her shifting away from an earlier, loose identification with Latin American expatriates, and towards a much more broadly transnational perspective. She knew to be circumspect in these as in other "Recados": she omitted to mention, for example, that she was in Portugal as a guest of the recently-established right-wing dictatorship of Salazar. Nor did she name her fellow-travelers, distinguished liberal Catholic intellectuals -Unamuno, Maeterlinck, and Ernst-Robert Curtius- who'd later urge Chilean President Arturo Alessandri to move her from a temporary to a better paid, more permanent job.

Mistral's first published writing about Portugal, her recado on Eça de Queiroz, was composed at the end of 1934 and published the following year. The recado's central topics reflect Mistral's overriding preoccupation with making ends meet as a working writer and a consul with significant family responsibilities. She relates how Antonio Eça de Queiroz, son of the famous Portuguese writer and consul, hosted Mistral and other writers in a visit to Lisbon. She interviews the son, who describes how his father's commitment as a writer never touched on his consular duties. She provides particular detail about how Eça de Queiroz enjoyed a stable family life as Portugal's consul to London. The essay could be seen as a kind of wish-fulfillment in her focus on precisely the elements in Eça de Queiroz's life that she most lacked: recognition in Chile and a steady salary abroad. Describing the Portuguese consul's life enabled Mistral to imagine how it might feel to be admired from afar, in her home country, while being able to work productively as a writer and earning a consular income sufficient to support her household.

Concern for the lives of foreigners, migrants and stateless persons which would dominate many of Mistral's writings from Portugal is also evident in how her

25 Gabriela Mistral survived in Madrid in substantial part by drawing on her savings: Gabriela Mistral, letter to Carmela Echenique, 25 Jan. 1934, in Vuestra Gabriela: Cartas inéditas de Gabriela Mistral con los Errázuriz Echeñique Tomic, Luis Vargas Saavedra (ed.), Santiago, Zig-Zag, 1995, 2529, rpt. Vargas Saavedra, op. cit., 76-77. Those savings subsequently lost half their value over that year, with the fall of the dollar: Gabriela Mistral (signing as "Lucila Godoy"), letter to Pedro Aguirre Cerda, 10 Dec. 1934, in Magda Arce and Gastón von demme Bussche (eds.), Proyecto preservación y difusión del legado literario de Gabriela Mistral, Santiago, Zig-Zag, 1993, 152-153.

26 Palma Guillén first visited Portugal not as a diplomat or as Mistral's companion but as a writer: Carlos d'Ambrosis Martins issued her a press credential, dated 24 Nov. 1934, Dana Atkinson Archive. D'Ambrosis was the Paris-based agent for both Vasconcelos and Eduardo Santos. Gabriela Mistral's interest in contacting consuls in regions adjacent to Spain, along with her perennial search for warm weather probably inspired her visit to Tangier, by way of Gibraltar, registered in the diplomatic passport in the following February: see Lucila Godoy diplomatic passport, 1934, Dana Atkinson Archive. 
essay on Eça de Queiroz marks her first use of the Portuguese term "saudade", which soon became an index of her identity as a migrant between the Portuguese and Spanish speaking worlds. "Saudade" as "una habla tan viva, que casi sangra su nostalgia del país" presents a broadly Iberian American, spoken, poetic identity, as opposed to a particularistic national, political identity ${ }^{27}$.

The situation of Jews as migrants who were about to be deprived of citizenship is a concern that vividly informs the other essay that Mistral wrote following this first, quasi-diplomatic trip to Portugal. Her approach to the topic reflects her contact and friendship with another of the travelers in Portugal: the Bonn-based Alsatian Catholic, Romance language professor Ernst Robert Curtius specialized in Proust and in the Latin Middle Ages. Curtius had witnessed the effects of Germany's official anti-Semitism in the Universities. Like Mistral and others in the group, he recognized Portugal and Gibraltar as logical ports of exit for Europe's rising numbers of frustrated emigrants, precisely the people whom Mistral would begin encountering in the months and years to come, as they sought to leave Europe.

Mistral wrote and published her essay, "Recado Sobre los Judíos" shortly after returning from Lisbon. Migration, anti-Semitism and human rights are a focus of this "recado". Her work as a consul, stamping passports and issuing visas informs her awareness, expressed in the recado's commitment to defending the human rights of stateless peoples:

"El judío alemán, o polaco, o lituano, ha carecido o carece del santísimo derecho de huida: se le regatea el pasaporte y si el hombre habilidoso descubre una escapada, se crea un tipo especial de paria que los consulados y las policías conocen: el hombre sin papeles sobre una frontera, el individuo sin nacionalidad [...]"28.

Mistral's publication of this recado in June 1935 contributed to newspaper debates over the Nuremberg Laws then being formulated in Germany. As in her previous writings on the situation of European and South American Jews, which appear during her residence in Punta Arenas in 1918, and which Scarpa points to as marking the beginning of her "exile", she is in favor of open immigration and she indicates both sympathy and support for the Jews as people who have been subject to hounding and murderous attacks. It's no accident that Mistral showed a growing awareness, even foreboding about the plight of the Jews in Europe in Punta Arenas as in Lisbon, two places at the watery edge of continents, places where she evidenced her own increasingly elastic identifications and destinies as a migrant intellectual.

Mistral's "Recado sobre los Judíos" opens with an analysis of French Catholic anti-Semitism, a topic that concerned Curtius, yet her essay takes a far broader perspective than his work did, for Mistral regarded the problem of Jewish

27 Gabriela Mistral, “Antonio Eça de Queiroz habla de su padre” (20 julio 1935), in Gabriela Mistral, Materias, prosa inédita, Alfonso Calderón (ed.), Santiago, Universitaria, 1978, 313.

28 Gabriela Mistral, "Recado sobre los Judíos" (16 junio 1935), in Gabriela Mistral, Prosa Religiosa de Gabriela Mistral, Luis Vargas Saavedra (ed.), Santiago, Andrés Bello, 1978, 47-50. 
emigration as belonging to what she called "Euro-Asian relations". Her use of the category of the "Asian" for Jews in 1935 -a form of shorthand and censorship, too, in her consular writings of the time- becomes all the more interesting when during World War II and later, she increasingly refers to American Indians as being of Asian descent: Mistral's belief that she descended from these two branches of an "Asian" tree is continuous with the Orientalism of her youth, which she never discarded, but continuously modified depending on her residence and interlocutors.

On her return to Madrid from her first, Christmas of 1934 trip to Lisbon, the poet was again thrown to grindstone of consular duties and scrambling to maintain two households and earn a living by writing. The challenges worsened when Palma received an appointment to serve as Mexico's Ambassador to Colombia. Palma departed in January of 1935, while Mistral remained in Madrid, stranded and seemingly immobile at the very bottom of Chile's consular ladder, despite her many efforts in maintaining the consulate, publishing in the newspapers, and receiving guests on behalf of Chile, in Madrid. Perhaps in an effort to save money, the poet moved from kitchenless attic rooms overlooking the Retiro, whose single advantage had been proximity to the park, the Prado, and the house of the Carlos and "Bebe" Morla Lynch, where she was an apparently infrequent guest. The poet cut her losses by taking a rented house in Ciudad Lineal, two trolley rides, and 40 minutes from central Madrid, where she praised the "atmósfera rural, dulce y limpio". Here, Luis Enrique Délano and his wife, Lola Falcón moved in for a while. The poet's nephew Juan Miguel joined the household before April of 1935, and may have remained behind when the poet made a second vacation trip to Portugal in June ${ }^{29}$. This second trip featured a two-week visit to the high-end beach resort of Estoril, feeding the poet's determination to leave Spain. Writing to friends in Chile, the poet praised Portugal as "verde y humano, muy superior a esta pobre Castilla" ${ }^{30}$. After listing Portugal's attractions - "El invierno es dulce, la tierra hermosa, y el costo de vida, un tercio más baja que España, gente muy semejante a la nuestra"- she began telling friends in Chile that she hoped to be in Portugal by the end of October ${ }^{31}$.

By mid-1935, complaints had become the leitmotiv of the poet's wide correspondence. Whether to improve her situation in Spain, or because she truly believed that Portugal would be better, she began to tell friends, quite openly that she expected to resign and leave by September or the year's end: "Yo sigo resuelta a irme a Portugal a fin de octubre o primera semana de noviembre, naturalmente renunciando a este famoso Consulado. Espero que el clima me convenga y voy a probarle antes de decidirme a plantar mi vida allí" 32 . This strategy or tactic had

29 A report card from shortly before Gabriela Mistral's move to Lisbon indicates that "Jean Michel Godoy" attended the French School in Madrid, where he ranked 21 $1^{\text {st }}$ in his class of 24: JeanMichel Godoy, Lycée Française de Madrid, 1935-1936: Dana Atkinson Archive.

30 Gabriela Mistral, letter to unidentified recipients, probably María Monvel and Armando Donoso, approximately June-Sept. 1935, Archivo del Escritor, 240.

31 Gabriela Mistral, letter to Graciela Préndez de Menéndez, 4 Sept. 1935, in Mistral, Antología Mayor III, op. cit., 224.

32 Mistral, letter to Teresa de la Parra y Lydia Cabrera, op. cit., 213. 
operated in all of her previously successful promotions and transfers, beginning with Punta Arenas, where she had praised and made friends in the neighboring country, publishing and enlisting writers to her side, all the while telling her associates in Chile that she was planning to resign and move.

With Chile being ruled by the right-wing regime of Arturo Alessandri, Mistral turned to the more conservative of her friends. Argentina's PEN Club wrote to Alessandri on her behalf: this was a somewhat liberal, non-communist group, as its members had intervened, in 1930, asking Spain to spare the life of deposed dictator Primo de Rivera on humanitarian grounds. Most prominent among Mistral's supporters was the international group of fourteen eminent European writers, many of whom had traveled with her to Portugal, or worked with her in the League of Nations. They petitioned Chilean President Alessandri on her behalf, telling him that she deserved regular employment.

The poet was running out of patience and growing frustrated by her complete dependence on other people while the process seemed to give little evidence of moving along. Apparently high-level Portuguese officials had to indicate their willingness to receive Mistral, for Alessandri cabled Chile's Encargado de Negocios in Portugal, in June of 1935, who communicated in turn with Dr. Julio Dantas, a Lisbon-based physician, writer, and future Ambassador to Brazil. Although Alessandri promised imminent legislation on Mistral's behalf, another three months would pass before the promise bore fruit ${ }^{33}$. On September 17, 1935, Chile's legislature voted and the President signed into law a bill that the poet described to various addressees as "un Cuento de 1001 Noches", both for its fairytale quality and significant delay. "The new law gave her a permanent, professional consul rank and the right to choose her residence" although this latter factor much varied in practice. Her consular income rose almost three-fold. Pedro Aguirre Cerda explained that it still wasn't enough to live on, but he promised better conditions once the Radicals, "ahora en oposición violenta al gobierno" entered power ${ }^{34}$.

Defeat was snatched from the jaws of victory. Only three weeks after the bill's passage and ten days prior to "El Día de la Raza" (or, de la Hispanidad), an ingenuous young journalist, followed by unknown enemies in Chile leaked a private letter that Mistral had sent to two friends, four months earlier, at the height of her multiple, many-flanked attempts to improve her situation in Spain $^{35}$. Her letter had vented the frustration of an afternoon wasted in taking tea in the Lyceum with the wife of the writer Ricardo Baeza. "Allí, entre pasta $y$ pasta”, María Baeza

33 Arce y von demme Bussche, op. cit., 184.

34 Pedro Aguirre Cerda, letter to Lucila Godoy (Gabriela Mistral), 27 Sept. 1935, in Arce y von demme Bussche, op. cit., 154.

35 "Unknown enemies": "El Hermano Errante", (Augusto D'Halmar, nee Thompson) is described as responsible for the leak, in collaboration with Marta Brunet, editor of the magazine that published the letter, according to Cartas salidas del silencio, Thomas Harris, Daniela Schütte and Pedro Pablo Zegers, Santiago, DIBAM / Lom Ediciones / Archivo del Escritor, 2003, 150-51. 
"se despachó largo y tendido sobre su experiencia en Chile, país del que acababa de regresar con su marido y adonde ambos se habían trasladado en 1931 como embajadores de España. Habló María Baeza sin ningún miramiento de amigos y conocidos de Gabriela y de algunos chismes que la pobre dama conoció en su estancia santiaguina" ${ }^{36}$.

The letter consisted of thirty-three pages torn from a block, written in pencil "con correcciones hechas al correr", full of the harshest criticisms toward Spain and composed with absolutely no thought of publication. Now, four months later, with the ink still fresh on that special law for her, the letter made its way into a folder and from there into an otherwise apparently friendly article which furthermore included ample quotes from the letter's text along with facsimile materials that would make the materials impossible to deny. Unknown enemies made copies of printed article. Third parties underscored in red the most inflammatory lines of her letter and sent copies to members of Chile's Spanish colony.

Relevant to Portugal is the letter's critique of Spain's failed colonialism as compared with its idealized neighbor, followed by a request for the writer's request to transfer:

“También él [Portugal] perdió colonia sabiendo guardar algo y que no es poco. El perder no lo ha empozoñado de odio contra todos. Es una raza con ternura, con amor, de idioma a su semejanza, dulce y prócer. Hay en él una atmósfera de poesía y religiosidad. Su convivencia es suave como la italiana y es fácil. Donoso, por qué no tendría Ud. lástima de mí y conseguiría el que me manden a vivir a ese país vivible?".

From here, the writer proposed to replace Chile's consul in Lisbon, “que es solo Encargado de Negocios [...] Me haría feliz"37.

Chile's Spanish colony responded with what Mistral later termed "un furor godo-colonial" 38 . They published their objections, went to Spain's Ambassador, and demanded justice. Chile's Ministry of External Relations sent two telegrams to Madrid. The second came in code. Her future was completely uncertain. "Hasta ulterior resolución del Ministerio, con relación a sus futuras actividades, la señorita Godoy no tendrá oficina consular a su cargo en este país"39 " "En comisión de propaganda, Nuestro cónsul en Madrid, señorita Lucila Godoy" consul second class, had forty-eight hours to leave for Lisbon ${ }^{40}$.

36 Caballé, op. cit., 241. Ricardo Baeza was one of several new and less experienced ambassadors appointed to represent the Republic following the 1931 fall of the Spanish monarchy.

37 Gabriela Mistral, letter to María Monvel and Armando Donoso, 15 May 1935, in Cartas salidas del silencio, op cit., 56.

38 Gabriela Mistral, letter to Victoria Ocampo, 7 April 1936, in Esta América nuestra, Correspondencia, 1926-1956, Elizabeth Horan and Doris Meyer (ed.), Buenos Aires, El Cuenco de Plata, 2007, 50 .

39 Gabriela Mistral (as "Lucila Godoy"), Oficio Consular, 24 Oct. 1935, in Mistral, Antología Mayor III, op . cit., 241.

40 "48 horas": Luis Enrique Délano, Sobre todo Madrid, Santiago, Editorial Universitaria, 1969,65 . 
Thanks to the unauthorized publication, Mistral had no time to pack books and papers or say goodbye to friends. "Le fue otorgado su deseo, pero en circunstancias desagradables y ofensivas" 41 . From her new residence in Lisbon, the ex-consul of Madrid and her friends responded with detailed memos and publications in her defense.

FINISTIERRA AND LISBON, NOV. 1935 - APRIL 1936: "LA ACEDÍA DE TENER POSADA Y NO PATRIA EN EL PLANETA ES TAN PERFECTA ${ }^{42}$ [...] AQUÍ ESTOY EN ESTOS ANGÉlicos PORTUGALES"43

Five weeks after her arrival in Lisbon, Gabriela Mistral published her "Recado sobre el poeta Anthero de Quental, el portugués" (24 Nov. 1935), on the poet and Buddhist outsider from the Azore Islands. This revealing mini-biography meditates on "saudade" as a metaphysical condition of exile: "la saudade portuguesa, tantas veces dicha, multiplica sus nombres hacia más y más atributos, hasta llegar donde se quiera, como las materias imponderables" 44 . From the essay's opening with Finistierra, Portugal's location is crucial to the writer's imagining a broadly Iberian perspective beginning from Portugal's maritime (that is, trade and colonialist) history. This approach leads her to point to the irony of Portugal's literature being marginalized with respect to Europe, despite the country's central location for oceanic travel. From both Finistierra and Anthero's origins in the Azores she imagined an alternative, off-shore version of the European body, with water as the world's bloodstream: "Portugal: ruta de agua, raza de aurículas europeas y ventrículos afroasiáticos" 45 .

Autobiographical elements pervade this essay. The writer stands literally on the furthest western strand of Europe, turning her back on the Spain that rejected her, facing the Atlantic and Brazil, to which she quite likely expected transfer. Her turn from Spain to Iberoamérica was also a turn from a single-country perspective (such as Chile or Spain) towards a broader horizon within the Americas, evident in Tala, the (yet unnamed) book of poetry on which Gabriela Mistral had been working in Spain. In Portugal, she moved that book closer to completion.

Location much matters for the poems of Tala. Some poems reflect the Mediterranean and inland Spain. Others specify the Atlantic and the Caribbean. In

41 Vargas Saavedra, op. cit., 221.

42 Gabriela Mistral, "Recado sobre Anthero de Quental, el Portugués", in Gabriela Piensa En, Roque Esteban Scarpa (ed.), Santiago, Editorial Andrés Bello, 1978, 368.

43 Mistral, letter to Victoria Ocampo, 7 April 1936, op. cit.

44 Mistral, "Recado sobre Anthero", op. cit., 368. "[Saudade] significa melancolía a secas y entraña luego una dulzura apesadumbrada; ella vale por una sensación estable de ausencia o de presencia insólita; ella es metafísica y se colorea de un nostalgia aguda de lo divino; ella toma la índole de una cosa temperamental permanente y la de una dolencia circunstancial y ella se sale de lo portugués y se vuelve un achaque humano universal, un apetito de eternidad que planea sobre nuestro corazón temporal". Saudade also appears in her subsequent writings from Brazil and becomes synonymous with the mood of her exile, in her January 1938 speech in Montevideo, "Como escribo".

45 Ibid., 362. 
Lisbon she added the poem "Cordillera", representative of the Andes ${ }^{46}$. She described the text overall as "un libro de versos de diez años", produced "después de 12 años viajando", "un libro de partes diversas y aún opuestos", "de versos, muy heterogéneo, surtido y revuelto" 47 . Working on this mixed book while living in Lisbon would push her to consider: what relation might the mixed race and criollo peoples of lands formerly controlled by Spain and Portugal have towards the former colonizers? The question runs like an oceanic undercurrent through all of her letters and actions regarding the Spanish Civil War, underlying her prose recados on the Portuguese figures and situations of Eça de Queiroz, Anthero de Quental, of Magellan, and even the medieval King Pedro I, along with her new essays on Mexico and on Chile, from Portugal.

Further autobiographical aspects of the writer's essay on Anthero de Quental are reflected in the allusions to Juan Miguel Godoy's presence in her life, as the writer muses on why the Portuguese poet adopted two children. "Ha de haber sido esta adopción un apetito de infancia en torno y otra forma de la saudade infinita. Ver niño, tocar niño, tener niño en la mesa, y justificar la casa, un huerto y otras regalías con esas chiquitas, todo eso buscaría con esta aventura de seudo paternidad" 48 . She speculates on the inner life of Anthero de Quental, who never married and apparently had no lovers, in terms relevant to herself: "el caso del trueque de Eros físico por el Eros metafísico ha sido bastante frecuente en latinidades y asiatitudes, díganlo desde el señor Buda hasta el judío portugués Spinoza"49.

Reading Anthero de Quental and other Portuguese writers accentuated Mistral's growing clarity in exploring the liminal world of dreams, phantoms, and madness. She continued to read Guerra Junquiero, her old favorite, still appreciating the "crudeza" of his "blasfemias" 50 . She wrote that the "Visión Nocturna" by Anthero de Quental ran through her head twenty times a day ${ }^{51}$. Her new volume devoted greater space to supernatural themes than had Desolación. Both volumes were possible only thanks to her "larga penitencia de Castilla". Portugal, by contrast, was a blessing: "[...] me la han compensado los dioses menores que Uds. llaman ángeles y que tal vez son los únicos que pueden abajarse a nuestras miserias, dándome esta dulzura de Portugal, este reposo que llega a parecerme un cuento"52.

46 Further evidence of the poet's widening perspective appears in that she was living in Lisbon when she sent "Cordillera" and "Sol del Trópico" to Eduardo Santos, a Colombian, thanking him for his hospitality to Palma Guillén, a Mexican, while reminding him that "Cordillera" was more appropriate to Peru, a country in which she had lost two Peruvian friends, the García Calderón brothers, who saw Santos' influence in her backing Colombia over Peru in a dispute in 1931.

47 Gabriela Mistral, letter to Eulalía Puga, 12 Nov. 1936, in Mistral, Antología Mayor III, op. cit., 259; Gabriela Mistral to Pío Baroja, 1 May 1937 [sic: 1939], in Vargas Saavedra, op. cit., 239-240.

48 Mistral, "Recado sobre Anthero", op. cit., 365-66.

49 Ibid.

50 Gabriela Mistral, letter to Federico Henríquez, Nov. 1920, in Julio Jaime Julia, Gabriela Mistral y Santo Domingo, Santo Domingo, Centro de Investigación para la Acción Femenina, 1989, 288-289.

51 Mistral, "Recado sobre Anthero", op . cit., 367.

52 Gabriela Mistral, letter to C. Zardoya, 19 Feb. 1936, in Mistral, Antología Mayor III, op. cit., 252. This supernatural element later developed into her praise of Portugal's Marianism: see Mistral to Pío Baroja, op . cit., 239-240. 
Angels and doorways populate her writings from Lisbon. She represented Portugal as antithetical to Spain, a germ-borne sickness. Thus the convalescent poet maudit concluded one of her most extraordinary letters, summarizing her rejection:

\begin{abstract}
"Se me hizo España [...] Venía, pues, malherida. Me dirán ustedes que debí llegar ya vacunada. Pero es que para el odio y para la estupidez nunca estaremos vacunados. [...] Todo esto [...] estaba agazapado en mí como esos bacilos que irrumpen cuando las defensas flaquean. Ya ha pasado el fiebrón. Convalezco. [...] Portugal es una dulzura no [...] española, que me irá sanando, día por día, con solo mirarle, desde la ventana, su luz y sus nubes" 53 .
\end{abstract}

Language and geography emerge as primary concerns, in her first month in Portugal. They appear in her description and allegory of Finistierra as "la Tierra acaba, mentando el planeta a la europea". Language was softer here than among English-speaking neighbors to the north or Spanish-speakers to the east: "Acaban las lenguas duras, el inglés hacia arriba, el español hacia abajo, apagándose en la esponja de la lengua portuguesa" 54 . Portugal embodies and offers the objective and the subjective, "navegación y ensueño"55. She finds in Portugal an ethereal alternative to the will to power and domination which she regards as embodied in Spain's language: "la soberana lengua hecha para decir este mundo en sus esencias. Una lengua en la cual se alían Goya y Velázquez, Manrique y Béquer, Santa Teresa y Unamuno" 56 . The poet's unforgettable recollection of Unamuno as a Christianized but essentially pagan god depends on language: "cuando hablaba era como un Júpiter bautizado" 57 . By that same measure of language, he was a fierce and unrepentant colonialist, con "un desprecio olímpico, caucásico, es decir, nazi, respecto del indio americano. No salvaba a ninguno. Ni siquiera a los mayas"58.

Gabriela Mistral's Spanish-speaking peers disdained her enthusiasm for Portuguese as a great literary language. Spanish poet Juan Ramón Jiménez was dismissive. "Vieja analfabeta", he told his group; he then enumerated her perceived errors in his diary 59 . By contrast, Gabriela Mistral's reading, translations, and friendships among Portuguese language poets would, in the upcoming years, exemplify her generosity ${ }^{60}$. To her last days she insisted on French and Portuguese as "the best languages for poetry" 61 . While French was sine

53 Gabriela Mistral, letter to Palma Guillén and M. Arce, 1935, in Mistral, Antología Mayor III, op. cit., 233.

54 Mistral, "Recado sobre Anthero", op. cit., 361

55 Ibid., 362.

56 Gabriela Mistral, letter to Palma Guillén, 1936?, in Vargas Saavedra, op. cit., 223-226.

57 Idem

58 Idem.

59 Juan Ramón Jiménenz quoted in Marta Vergara, Memorias de una mujer irreverente, Santiago, Editorial Nacional Gabriela Mistral, 1974, 276; Vargas Saavedra, op. cit., 220-221.

60 On Mistral and Brazil, see Ana Pizarro, El Proyecto de Lucila, Santiago, Lom Ediciones, 2005; and Karen Peña, Poetry and the Realm of the Public Intellectual: The Alternative Destinies of Gabriela Mistral, London, Modern Humanities Research/Legenda, 2007.

61 Gabriela Mistral, voice recordings made by Doris Dana, early 1950s, Dana Atkinson Archives, digitized in Washington, and now in the Archivo del Escritor. 
qua non for any serious writer of the time, Mistral chose boldly when she made Portuguese central to her public identity, accepting the Nobel as "la voz directa de los poetas de mi raza y la indirecta de las muy nobles lenguas española y portuguesa".

The poet's domestic life in Portugal was initially tranquil. By December of 1935 she had leased an apartment on the fourth floor at Avenida Augusto Antonio Aguiar, 191, opposite a lovely park, half-way between the city's downtown and outskirts ${ }^{62}$. She now admitted that her malaise long predated her residence in Spain: "Este clima portugués me va levantándome y hasta creo que me cure, aunque es cosa muy vieja mi mal de riñones, iniciado en el destierro de la Patagonia"63. Yet she never described Portugal as "un destierro". Rather, the two faces of Iberia enabled her to continue an earlier theme. Like modern Chile, Spain was industrialized, endless mechanical labor. Like Mexico in its ruralism, Portugal was "sosiego", a "tierra blanda y regaloneadora de ojos y de espíritu", vacations and convalescence ${ }^{64}$.

Two Puerto Ricans, Margot Arce and Consuelo "Coni" Saleva, provided secretarial and editorial assistance that aided the writer's newfound "sosiego". Arce had first met Mistral in Madrid, while Coni had been Mistral's student in the United States. The latter provided paid assistance to the poet for years to come. The poet's friend, the Spaniard Victoria Kent, a congresswoman from Málaga who'd also served as Director of Prisons, was delighted to learn that Coni would join the poet in Lisbon:

"Me alegra y tranquiliza saber que su salud va mejor, no se abandone y cuando llegue Coni, si Ud. me lo permite, le escribiré diciendo que Ud. necesita cuidados de niño, que hay en su casa dos pequeños, a los efectos del celo en los cuidados, Gabriela y Yin Yin. Veo que me atrevo a decirle por cierto lo que, quizá, nunca de hubiere dicho de palabra, delante de Ud." 65 .

Few but disturbing indications place the poet's ten-year-old nephew, Juan Miguel "Yin Yin" Godoy Mendoza, with her in Portugal. Some ten years later, Hans Flasche, a German who'd been the poet's houseguest in Lisbon, subsequently accompanying her to Hamburg, wondered of the boy, “¿Es él con quien yo asistí frecuentemente a la misa en una pequeña iglesia cerca de la Avenida Augusto Antonio Aguiar?"66. When the Chilean writer Luis Enrique Délano came to visit from Madrid, he was surprised when the boy greeted him -newly-bearded- as a stranger, although the two had shared much time together in Spain, only a year earlier (94-95).

62 By the following year, Gabriela Mistral had moved a block away to Rua Ramalho Ortigao, 35 : Mistral, letter to Eulalía Puga, op. cit., 259.

63 Gabriela Mistral, letter to María Urzúa, 17 Dec. 1935, Archivo del Escritor, 507, 572.

64 Gabriela Mistral, letter to Victoria Ocampo, 7 April 1936, op cit., 52.

65 Victoria Kent, letter to Gabriela Mistral, 23 Nov. 1935, Gabriela Mistral Collection, Library of Congress microfilms.

66 Hans Flasche, letter to Gabriela Mistral, 17 June 1947, Gabriela Mistral Collection, Library of Congress microfilms. 
Concern with war pervades Juan Miguel's drawings, full of airplanes and apartment buildings. Other drawings - probably from a later date- suggested that he was attracted to the military life. Many years later, Palma Guillén somewhat uncertainly related that "el motivo de este viaje" from Portugal to Brazil "fue que Juanito, un chamaco todavía, se mezclaba con sus amigos de la escuela, en las "Mocedades" "67. Whatever the case, the group of Mexican diplomats with whom Mistral became involved in Portugal clearly knew about the boy. (Seven years later, after the boy's suicide in 1943, she'd send Daniel and Ema Cosío Villegas and Dr. Pedro de Alba one of the earliest copies of the "carta en cuadrilátero" in which she attempted to make sense of his death.)

Amid the poet's pleasure in Portugal, she began to write almost promotionally about Lisbon, working to attract visitors and houseguests. On her birthday in April of 1936 she wrote a letter to Victoria Ocampo: "Aquí estoy en estos angélicos Portugales. Casi son la América del Sur. Llueve demasiado, pero como no hay frío, no sufro". Her "seis meses lusitanos" were "dulces para curarse, para convalecer y para envejecer también. Aquí me la quisiera y conversaríamos sin pasaportes y [...] sin cóleras castellanas [...]"68.

One of the poet's numerous houseguests was Roberto Matta, who'd become one of the $20^{\text {th }}$ century's great surrealist painters. By Matta's recollection fifty years later, he showed up in about August of 1936, an impoverished, poorly-fed twentyone year old vagabond who'd left Madrid, where his aunt Bebé was married to Carlos Morla Lynch, Mistral's former boss in the Chilean Legation. In Lisbon, Matta reports, the poet fed him and let him stay on, developing into what he called his "romántico amor" with her: "[...] me enamoré de ella y le pedí su mano. Ella me dijo que podía ser su abuela y que me callara y que me fuera para el otro cuarto"69. By Matta's report, she kept him around to help copy over her verses before trundling him off to London with a third class ticket and a letter of introduction to Agustín Edwards, publisher of El Mercurio and Chile's powerful Ambassador to England.

\section{LISBON, AUGUST-SEPT. 1936: "NOTICIAS COMO PARA QUEMAR LA CARNE"}

Five weeks after the July 1936 outbreak of Civil War in Spain, the writer had little time for lovesick boys. In a letter to Victoria Ocampo she details her shock at

67 Guillén quoted in Víctor Alba, "Mistral vista por su amiga y secretaria", in Anales de la U. Chile 106, Santiago, 1957, 92. There are holes and inconsistencies in Alba's report of Guillén's accounts of the boy regarding the "Mocedades" (a compulsory fascist youth organization founded in 1936) and his move "from Portugal to Brazil". For example, Guillén completely omits the two and a half years that the boy spent with her, which are corroborated by the boy's passport and in Palma's letters to Gabriela Mistral: Juan Miguel left Lisbon not to go to Brazil, but to join Palma Guillén in Copenhagen at Christmastime in 1936. He accompanied her to Geneva a year and a half later, and did not rejoin the poet until the middle of 1939, in France.

68 Mistral, letter to Victoria Ocampo, 7 April 1936, op. cit., 49.

69 Eduardo Carrasco and Roberto Matta, Conversaciones con Matta, Santiago, CESOCCENECA, 1987, 69 . 
the war's carnage. "Acabo de leer en tres diarios y en dos versiones, la muerte de Ramiro de Maeztu, fusilado en Madrid [...] el diario de hoy trae unas noticias como para quemar la carne. Yo espero que no sean ciertas las de los fusilamientos de Benavente, los Quinteros, Zuloaga, etc."70.

Mistral and Ocampo commenced rescue operations. María de Maeztu, whose brother was probably killed for his and his family's close ties to monarchist Navarre, was the first person whom Mistral and Ocampo helped escape to Buenos Aires. As the poet observed of María, her residence in Madrid made her a target for the left: "La odian muchas, pero muchas, mujeres de izquierda"71. Thoughts of Ramiro de Maeztu's death haunted Mistral: his signature had been one of those on the petition to Alessandri, yet she'd been unable to help him, in turn, in all the awful news from Spain. Where to begin? People began to show up at Mistral's residence in Lisbon.

Another of the earliest people whom the poet helped, enlisting further assistance from Victoria Ocampo, was the libertine avant-garde artist Maruja Mallo, who'd been caught in her native Galicia, where she'd been working with a troupe of actors when the war broke out. Maruja Mallo recognized that she should move quickly: she slipped over the border and was the poet's valued guest for several weeks in Lisbon before shipping out to Buenos Aires. Mistral furnished Maruja Mallo with exemplary letters of introduction to both Ocampo and Alfonso Reyes, who was serving as Mexico's Ambassador to Argentina: "Le lleva estas palabritas Maruja Mallo y se lleva ella misma como la mejor presentación"72. Mistral's pleased response to the news of Mallo's safe arrival shows how quickly the war focused her: "Me aliña la conciencia Americana"73.

Breakdowns in communication brought false rumors, for example, that "red" (actually, anarchist) militias operating in Madrid and in the Basque country had imprisoned Tomás Navarro Tomás, Director of the Biblioteca Nacional. Mistral's plans to help him leave Spain show her willingness to overlook ideological and personal differences. The gravity of the situation pushed her to work with people across wide ideological divides. These included people whom she actively disliked, such as Chile's Ambassador to Spain, who was actively hostile towards the Republic. She even proposed to approach people whom she regarded as personal enemies, that is, rivals such as the pro-Mason, pro-Radical Amanda Labarca $^{74}$.

Complicating Mistral's efforts to aid people in leaving Spain was that she had to work around the Chilean government under Alessandri, which was not at all sympathetic to the Republic, and which had trading interests with Germany, which was actively aiding the Nationalist insurgents. To some extent Chile may have

70 Gabriela Mistral, letter to Victoria Ocampo, 21 Aug. 1936, in Esta América nuestra, op. cit., 55. Idem.

Gabriela Mistral, letter to Alfonso Reyes, 24 Jan. 1937, in Tan de Usted, op . cit., 107.

Gabriela Mistral, letter to Victoria Ocampo, 24 Jan. 1937, in Esta América nuestra, op . cit., 57.

Gabriela Mistral, letter to Alfonso Reyes y Enrique Diez Canedo, 5 Sept. 1936 [sic: 1939]; rpt.

Tan de Usted, op. cit., 120-122; Mistral, Antología Mayor III, op. cit., 300-302. 
followed the lead of Britain, whose business interests argued for non-intervention. As the war developed, splintering the various factions that had assembled the Frente Popular, Mistral's humanitarian rather than ideological perspective distinguished her from many Latin American intellectuals, whose support for the Republic veered towards the left. But Mistral's closest political friends and intellectual colleagues among Latin Americans were not part of the Chilean government, or even closely related to Chile at all. Rather, within the ranks of consuls and diplomats, the ones who took her most seriously were Mexican intellectuals who served as consuls, charge d'affairs, and diplomats. Her friend Alfonso Reyes is a case in point, of how countless Mexicans were pleased by the "expectation of Mexican- style reforms in the peninsula"75. Also, many conservative, Catholic Mexicans welcomed the Republic in 1931, for this gave them hope of bringing greater 'democracy' to Mexico. While many Mexican leftists had regarded traditional Spain with disfavor, they were quite sympathetic towards the new Republic ${ }^{76}$.

Thus, Chile and Mexico, the two Latin American countries where Mistral has the most friends employed in government service, held diametrically opposed positions towards on Spain's Republican Government. Mexico's strong support for the Republic (a.k.a. the Loyalists) was the opposite of the then-conservative Chilean government's inclination to support the traditionalists. An immediate consequence of the Chilean government's cool relations towards the Spanish Republic came when war broke out in Spain: Chilean Ambassador Aurelio Nuñez Morgado proposed that all foreign envoys should leave Madrid because its government could not guard their safety"77. But Mexico's Minister, Francisco Navarro, opposed the Chilean Ambassador: Navarro declared that Mexico's left wing government solidly backed the Madrid regime ${ }^{78}$. Navarro's declarations of support were followed by action: Mexico sold arms to Madrid and eventually accepted more than 30,000 exiles from Spain; Mexico never recognized Franco's regime ${ }^{79}$.

Specific evidence of how Mistral worked with Mexican diplomats comes from a study of the actions and memoirs of her close friend, the Mexican economist, historian and occasional diplomat Daniel Cosío Villegas. The two of them worked to develop routes of escape so that endangered intellectuals could get out of Spain.

75 Falcoff and Pike, op. cit., 55. Alfonso Reyes'vantage as Mexico's Ambassador to Argentina made him aware of how, in October of 1936, fascists sought to influence the Argentine government against the Republic. He declared that "a thousand Fascist influences and pressures within and without the government were working against the Spanish Republic" (Reyes qtd in Falcoff and Pike, op. cit., $70)$.

76 T. G. Powell quoted in Falcoff and Pike, op. cit., 53.

Ibid., 61 .

78 Idem

79 Although the reasons for Mexico's sympathy towards the Republic were multiple, Powell argues that after General Lázaro Cárdenas broke with his patron, Calles, Cárdenas wanted to appear more leftist than he was, which prompted Cárdenas to extend assistance to Spain from Mexico, and that Mexico's assistance became stronger after the Republic itself moved leftward in February of 1936: see T. G. Powell in Falcoff and Pike, op. cit. 
Mistral learned quickly and well from this old friend: the two had known one another ever since the poet's days in Mexico City, when he'd been an elected student leader and had worked (literally) elbow-to-elbow, as Vasconcelos' righthand-man in the Secretaria de Educación, in the very years when Mistral had come to México from Chile.

In the intervening years, Mistral had been living in Europe with Palma Guillén, while Cosío Villegas had left Mexico for study at several universities in the United States and Europe. He'd subsequently returned to Mexico to lead a university and start a publishing house, the renowned Fondo de Cultura Económica.

If Cosío Villegas's entertaining but somewhat partial memoirs are to believed, he'd just accepted a position in Lisbon as Mexico's Encargado de Negocios in Portugal, anticipating a low-key family vacation, when the Civil War broke out. This made Cosío Villegas one of the few representatives in Iberia of the only nation (other than Soviet Russia) that officially supported Republican Spain. He describes how he and Mistral were under constant suspicion in Lisbon, where Salazar's government, nominally neutral, supported the Nationalist rebels by allowing covert shipments of tanks and other war materials to pass through Portugal en route to Spain.

It's clear from their letters and other writings that the Mexican and Chilean each took much pleasure in one another's company. Cosío Villegas describes her sense of humor, and he relates how her generosity ruined the spies that the Portuguese government sent to watch her: “[...] era objeto de una vigilancia policíaca continua, cosa que le divertía al grado de invitar a su perseguidor en turno a meterse en el cine con ella para evitar la espera, la lluvia o la nieve, y eso, por supuesto, pagándole la entrada" $\$ 0$. For her part, she told Alfonso Reyes of her happiness that Cosío Villegas had brought his family with him:

"Daniel es muy intelectual mexicano y varón fino de su país; la abuela es una súper abuela; Ema es una muchacha profesional y sensible [...] Los niños son una maravilla y yo los adoro [...] estaba viendo, de nuevo, no sé qué brujerías de esas del 'aura' de las criaturas, viendo, tocando, oliendo a México".

In all, the poet appreciated these "visible" reminders of her "raíces mexicanas" $" 1$.

A mandate from Mexican President Lázaro Cárdenas spurred Gabriela Mistral's and Daniel Cosío Villegas's work in Lisbon, to help intellectuals move from Spain to Mexico. The difficulty of movement in wartime coupled with the need to pass through other countries made Mistral's consular status and contacts in Barcelona, France, and elsewhere in Europe particularly valuable. As an economist, Cosío Villegas was particularly interested in Luis Nicolau d'Olwer, a Catalan who'd had been serving as Governor of the Bank of Spain for Azaña

80 Daniel Cosío Villegas, Memorias, México, Joaquín Mortiz, 1976, 170.

81 Gabriela Mistral, letter to Alfonso Reyes, May 1937, in Tan de Usted, op cit., 109 
since March of $1936^{82}$. Another important member of their team, working as Mexican consul in Southern France, was Dr. Pedro del Alba, a trained physician who'd served in the Revolution and had subsequently worked with Vasconcelos in Mexico. Finally, both Cosío Villegas and Mistral were delighted when Palma Guillén returned to Europe from Colombia, resigning the Ambassadorship after fifteen "infinitamente largos" months made worse by her bosses' plotting and attacks from both the Colombian and Mexican press ${ }^{83}$. When Palma returned to Europe, she visited both Portugal and wartime Valencia before going on to direct Mexico's Legation in Copenhagen. Palma's situation in Denmark gave the group a northern haven, close to Germany, through which Mistral traveled several times as she and others realized that not just Spain, but much of Europe was headed towards war. Palma would wind up staying longer in Europe than any of them, for she left Copenhagen for Geneva, where she worked for and with the Spanish Republican government in exile.

In Lisbon, Cosío Villegas and Gabriela Mistral met and wrote letters in order to determine who might be willing and able to leave for Mexico and elsewhere in Latin America. As their aim was to provide intellectuals with refuge, which became "La Casa de España en México", "a place in which to renew their activities until the war should end", they arranged and sent transit visas, tickets, money for travel, invitations and jobs ${ }^{84}$. Mistral had not just her own contacts in Spain to draw on, but those of her friends Alfonso Reyes, who'd lived for ten years in Madrid, as well as Victoria Ocampo, in Buenos Aires.

Mistral's "recados" offer indirect but contemporaneous testimony of some of her day-to-day concerns as she returned to her "Mexican roots" while living in Salazar's fairly repressive dictatorship and working, at least nominally, for a Chilean government that was sympathetic to the Nationalists. To avoid arousing suspicion when she wrote about Chilean and Mexican politics in June and July of 1936, she turned to the theme of "old myths" or folklore. "El Caleuche" seems to correspond to her view of the Chilean ship of state at the time, while her publications on the Mexican myths of Huitzilopochtli and Quetzalcoatl in the Costa Rica-based Repertorio Americano reminded her readers of her deep experience in Mexico. When she praised Pedro de Alba's biography of Las Casas, her description of his work fit her group's members as a whole, who were working devotedly, night and day, for "la causa de América [...] nuestro corazón mestizo"85.

82 Luis Nicolau d'Olwer's letter from Barcelona summarizes the increasing polarization during the city's final spring before the war: "Las derechas están de nuevo boicoteando el régimen, como en 1929. Nuevamente Cataluña aparece como un país aparte. Pacífico aquí: los odios son africanos y rusos y otros se dedican a casarse por las calles”, Luis Nicolau D’Olwer, letter to Gabriela Mistral, 12 March 1936, Gabriela Mistral Microfilm Collection, Library of Congress.

83 Palma Guillén, letter to Eduardo Hay, 10 June 1936, Dana Atkinson Archive.

84 Stanley R. Ross, "Daniel Cosío Villegas (1898-1976)", in The Hispanic American Historical Review 57:1, Pittsburgh, Pennsylvania, 1977, 97.

85 Gabriela Mistral, "Una Biografía del Padre Las Casas" (Oct. 1936), in Gabriela piensa en, op. cit., 285 . 
In March of 1937, she described Chileans as living with a "rapidez telúrica", as she was also doing at the time ${ }^{86}$.

It is not too much to stress that the poet's participation in the rescues was at once intense and covert, for she risked both her position and reputation. Portugal did not recognize diplomatic passports. Another forced transfer, or deportation, would have delighted her enemies and ended her consular career. Further, working as a consul tied Gabriela Mistral to Chilean business and political interests that were closely aligned with the Nationalists as Alessandri regime's headed steadily to the right. Alessandri's Recuerdos de gobierno (written, it must be said, in the midst of the Cold War) sympathized with Franco and regarded supporters of the Republic as communists.

When Mistral moved to Portugal in October 1935, she recognized that the real power in Alessandri's regime lay in the right-wing Ministro de Hacienda, Gustavo Ross Santamaría, "el mago de las finanzas", "el último pirata del Pacífico". "Ud. sabe que Ross tiene tantas o más atribuciones que el Presidente", she noted to a well-informed friend, scant weeks before her precipitous remove to Lisbon ${ }^{87}$. Ross was, as the poet accurately perceived, an important international figure, beginning with his base of support in the business community and most notably in country's nitrate and copper industries. She appears to have recognized Ross much as Joaquín Fermandois has later described him, as "un actor económico no estatal internacional, nombre un poco pedante para lo que era: un hombre de mundo y del mundo de las finanzas internacionales" 88 . At the same time, in "una época de gran influencia del mundo literario en la cultura política", Ross curiously showed little interest in "el mundo intelectual en general, menos por el chileno; sobre todo, poco interés por las ideas de la época [...]"89.

Mistral's relationship with Ross was complex. As with the other powerful men whom she counted among her acquaintances, she treated him as a near-equal, writing letters reflecting her verbal genius in combining honest flattery and sage advice, despite the fact that she was technically his subordinate. Fermandois, who has studied her letters to Ross, reports that she alludes to their prior conversations and that she urged him not to regard Salazar's Portugal as a model for Chile to follow. She was right to be concerned: Ross was soon standing as a candidate for election to the Chilean Presidency.

Despite Ross's growing power, Mistral dodged what he would have regarded as an overriding (because financial) interest: shepherding nitrate shipments through Portugal. As she recounts in a letter to her supervisor in Santiago, a Chilean resident in Salamanca had brought just such a proposal to her, relaying a message from the Nationalist zone. "Me contó que la gente oficial de Franco desea adquirir

86 Gabriela Mistral, "El Signo de la acción" (14 marzo 1937), in Gabriela Mistral: Escritos Políticos, op. cit., 42 .

87 Mistral, letter to Graciela Préndez, op. cit., 223.

88 Joaquín Fermandois, Abismo y Cimiento. Gustavo Ross y las relaciones entre Chile y Estados Unidos 1932-1938, Santiago, Ediciones Universidad Católica de Chile, 1996, 116.

89 Ibid., 117. 
un depósito grande de salitre" $" 90$. The sale was to be arranged through Lisbon, with Germany guaranteeing payment ${ }^{91}$. Rather than participate in this business, she professed to understand nothing. "Le respondí que yo no sé nada de estos asuntos" 92 . In the matter of shipments to Franco, she advised the representatives of the nitrate company to deal with the Ministry directly. In all: if Ross or any mining companies wanted to sell nitrate to Franco via Portugal, they would have to find someone else. Gabriela Mistral would not do their work for them.

\section{Lisbon, OCT. 1936 - APRIL 1937: “DE ESTE PoRTUGAl MEdio-ANGÉliCO [...] ME ACONGOJA SALIR DE ESTE REPARO Y REFUGIO AL AIRE TREMENDO DE ESO QUE LLAMAN LA DIPLOMACIA" $" 93$}

One person who definitely wanted Mistral out of Portugal was Carlos Azócar, Chile's Encargado de Negocios in Lisbon. He'd initially greeted her arrival in Lisbon. "Este jefe me ha maniatado por entero", she later confided to don Pedro ${ }^{94}$. Azócar, six years in the job, issued surprising instructions to the new consul. He charged her not to give talks, although she was explicitly assigned "en comisión de propaganda". "Se ha negado rotundamente a que yo las dé", she explained, "pues, según él, a Portugal no le importa nada de la América; porque, según él, la gente de aquí es muy necia y no lee ni escucha y porque el esfuerzo [i] no vale la pena!"95. Forbidden to give talks, she continued her journalism, "artículos de propaganda para cinco diarios de América; cosa que tiene a Relaciones muy contenta" 96 .

A more astute colleague would have recognized the newcomer as his likely replacement. She was sardonic in detailing how she and the Minister had good relations: "Tan cordiales son que cuando mi ministro sale a Alemania, por ejemplo, me deja a sus hijas, a quienes adoro; que vienen a mi casa ellos semanalmente y que él usa conmigo un trato hasta familiar" 97 . He also made her his confidante: "El hombre dice que Portugal ha deshecho su actividad de [hombre: tachado] joven, que la pereza nacional lo ha tomado y el pesimismo lusitano más que todo [...]"98.

Since Azócar forbade her from engaging in publicity, she sought an appointment as consul to Oporto. Santiago complied, but Azócar urged her not follow through. "Me dijo mi amigo Azócar que este gobierno ultra-conservador no querría a una mujer de Cónsul en Porto y que él prefería, por mi propio interés,

\footnotetext{
90 Gabriela Mistral, letter to Carlos Errázuriz Ovalle, 5 \& 7 May 1937, Dana Atkinson Archive. Idem. 
guardar las letras patentes y no presentarlas"99. Undaunted, she discovered "la indita en mí", and wrote a long-time, trusted friend who'd likewise worked for both the League of Nations and Eduardo Santos. "Pedí a un amigo del régimen preguntase al Ministro del Estado el asunto"100. The inquiry quickly produced the acceptance of her credentials, along with the Portuguese Chancellor's pleasure in learning that Gabriela Mistral, esteemed for her work in the League of Nations, had come to live in his country, which (contrary to what Azócar had said) had "una mujer Cónsul en Berna"101. But the matter didn't end there. "Su amigo Azócar al fin presentó las letras patentes; salió el exequátur y un ofrecimiento oficial de traslado a Guatemala"102.

Once the consul-poet realized that Azócar wanted her out, and that people in Santiago were backing him up, she turned to Pedro Aguirre Cerda. As Tagle Dominguez observes, the poet's letters to her protector reveal her primary concerns: "La nueva situación laboral, motivó nuevas consultas a Aguirre, en términos de gran confianza". The transfer to Guatemala puzzled her, she said. She hadn't sought it.

For many good reasons, she didn't want to leave Europe. Daniel Cosío Villegas likewise wanted Gabriela Mistral, with her contacts and networks, to remain in Lisbon for the duration of his own mission to bring high-powered intellectuals from Spain to Mexico. But Gustavo Ross, an admirer of Salazar, saw things very differently from Cosío Villegas. As Ross wanted Chile's financial picture to improve by way of increased exports to Chile's trading partners, paying in cash, he seems to have felt that Mistral's talents would be better employed in Brazil than in Lisbon. Ross had told her as much at some point in the first weeks of October of 1936, when he seems to have stopped in Lisbon en route to meeting with other financial figures in London. The Minister had been emphatic: "traía muy penosa idea de la representación" of Chile in Río. She should fill this "hueco" in propaganda about Chile by traveling to Brazil to give conferences ${ }^{103}$. Who could be better to promote Chile in Brazil? The famously tropical Mistral couldn't possibly complain of the weather in Río. Further, her well-known sympathy for writers in Portuguese would win friends. Ross could have had an unstated motive: to get his own man of business into Lisbon, someone who'd facilitate nitrate and other arms-related shipments.

Sharing Ross's enthusiasm for Mistral's transfer from Lisbon was Felix Nieto del Río, Chile's newly appointed Ambassador to Brazil. A gifted writer from Valparaíso, his friendship with the poet dated twenty years back, when they'd both contributed to Santiago's elite magazines. He'd left journalism to follow his older brother Carlos, who'd held diplomatic posts in Mexico during Mistral's residence there. Felix had been a Santiago-based undersecretary in 1932: in this year, his
99 Idem.
100 Idem.
101 Idem.
102 Idem.
103 Gabriela Mistral, letter to Félix Nieto del Río, 12 Oct. 1936, Dana Atkinson Archive. 
brother was posted to Brazil and Mistral received the consular appointment to Naples. But the real push to Felix Nieto del Río's career came from his successfully coordinating a Peace Conference in Buenos Aires in 1935-1936. The appointment as Ambassador to Brazil was his reward ${ }^{104}$.

Mistral couldn't easily refuse Ross, who'd announce his presidential candidacy in April 1937. She couldn't refuse Nieto del Río, who in 1936 had done the poetconsul a personal favor in recognizing Puerto Rico's delegates to the Peace conference: Puerto Rican sovereignty was the overriding concern of the various Puerto Ricans (including Coni Saleva and Margot Arce) on whose help Mistral had depended. Nor could Mistral refuse Pedro Aguirre Cerda, to whom she owed much, including the recent "ley especial".

Ross and Aguirre Cerda were political and temperamental opposites. Aguirre Cerda, known as "Don Tinto" for his extensive holdings of vineyards, began his working life teaching school, although he later studied law. Unlike the Valparaíso moneybags, Aguirre Cerda had risen up through elective office, beginning as Diputado from Los Andes in 1916. Ross and Aguirre Cerda would emerge as the two leading, rival candidates in the 1938 race for the Chilean Presidency. Yet they managed to agree in wanting Mistral out of Europe.

Gabriela Mistral turned to influential friends in Geneva and Paris to delay her departure from Europe. She wanted to stay, not just to work on behalf of noncommunist leftists from Mexico and Spain, but also to be close to Palma and Juan Miguel. Mistral's friends came through: the honors began pouring in by September of 1936, beginning with the poet's nomination to the Arts and Letters Council of the League of Nations ${ }^{105}$. In accepting the post and agreeing to attend three international conferences in Paris in the following June of 1937, she gained a ninemonth delay in her departure for Brazil.

Mistral wrote to offer her excuses. Only with Nieto del Río, who had to answer to the Francophile Ross, did the poet name-drop and stress the prestige factor: "[...] tengo una obligación que me importa cumplir. Me han nombrado miembro del Comité permanente de Letras de la Liga, el presidido por Valéry [...]"106. With her consular supervisor as with Pedro Aguirre Cerda in Santiago, she described the newly pending commitments in terms of national and continental representation. To Carlos Errázuriz she wrote: “[...] no hay ni otro chileno, ni otro sudamericano, y no aceptan reemplazantes [...]"107. To Pedro Aguirre Cerda and his wife, she explained how “[...] se junta las mejores cabezas europeas [...] no hay más americano que yo" 108 .

104 For more on the interesting relationship between Félix Nieto de Río and Gabriela Mistral, see Nieto del Río's correspondence in the Gabriela Mistral Microfilm Collection, Library of Congress, and Gabriela Mistral, letter to Arturo Alessandri Palma, 25 May 1936, in Arce y von demme Bussche, op. cit. 155-56; Mistral, letter to Félix Nieto del Río, op. cit.

105 Gabriela Mistral, letter to Montenach, 10 Sept. 1936, Gabriela Mistral Collection, Library of Congress microfilms.

106 Mistral, letter to Félix Nieto del Río, op. cit.

107 Mistral, letter to Carlos Errázuriz Ovalle, op. cit.

108 Mistral, letter to Pedro Aguirre Cerda and Juana de Aguirre, op. cit. 
In all, Gabriela Mistral's alternative plan benefited her and don Pedro while answering to Ross. She kept the salary for the three different positions. She remained in Europe through June, representing Chile and Latin America at three international conferences in France. She accepted "esa gira por América" in Brazil, while avoiding Chile for at least another year. She reminded Pedro Aguirre of how she was hesitant about Chile because of how the press treated her criticism of Spain: "la prensa de mi patria" had dragged her name "por el barro, en una campaña de injurias"109. She professed reluctance to leave "este Portugal medioangélico", a land of refuge: "[...] me acongoja salir de este reparo y refugio al aire tremendo de eso que llaman la diplomacia"110. As Aguirre Cerda had not yet agreed to enter the Frente Popular, she told him that she would avoid any form of recognizable party identification in relation to Chile's upcoming presidential campaign. Aguirre Cerda would have understood the poet's network of allusions and political counsels, which she lightly disguised as self-concern.

\section{EN ROUTE TO PARIS, MAY 1937: "LA LOCURA ES GENERAL, COMO EN LOS CARNAVALES"}

As the new year began, Mistral's relation with Chile's ex-Minister in Lisbon disintegrated into farce. As the poet explained to Carlos Errázuriz, the head of the consular division in Santiago, "nuestro ex-jefe Azócar" had deposited the consular papers with the Italian consul, indicating that Gabriela Mistral should be denied access. While she was out of her office, Azócar had entered and destroyed papers in front of her secretary. Over various months he'd also refused to assist one of the assistant consuls with a residence permit, "esperando que el señor liquidase un divorcio que tramitaba, pues su esposa, la señora Aldunate del Campo, se había dedicado a cantar en teatros de segundo o tercer orden. Obtenido el alejamiento de la señora, la Legación comunicó el nombramiento [...]"111. Suddenly a new difficulty arose: the assistant consul's former employer, the Remington Arms Manufacturer, launched an unjustified lawsuit against him. The ex-Minister made no moves to help. Gabriela loaned the assistant consul money, allowing him to leave Portugal before he was jailed.

Gabriela Mistral's account of how she'd dispatched the ex-Minister at the train station recalled others in which she'd bid goodbye to vanquished rivals:

"Fui a despedir a mi jefe a bordo y me dejó asombrada que no tuviese a bordo a ninguna persona del Ministerio, ni del Cuerpo Diplomático, ni a un amigo común cualquiera. Él estaba tan afectado de esta tristeza que me abrazó llorando, lloró un rato en mi hombro y me dijo, mirando hacia el Tajo:

109 Gabriela Mistral, letter to Pedro Aguirre Cerda, 30 Dec. 1936, in Mistral, Antología Mayor III, op. cit., 261.

110 Idem

111 Mistral, letter to Carlos Errázuriz Ovalle, op. cit. 


\begin{abstract}
'Gabriela, he vivido aquí siete años, he perdido siete años y no me queda ahí nada que yo deje sino el agua del río [...]'

Le contesté: 'Ministro, hay que querer para que nos quieran. Le diré como los budistas que en otra encarnación a usted y a otros chilenos como usted les tocará quererme y deshacer su injusticia o su ningún conocimiento de mi espíritu verdadero'.

'Vaya a Chile, me dijo, y allá la tendremos en nuestra casa y la querremos'.

Él está enfermo, a pesar de su buena apariencia; su hígado está mal, tal vez por este clima suave insidioso que parece ante-tropical" 112 .
\end{abstract}

From December of 1936 onwards, Gabriel Mistral traveled back and forth between Lisbon, Paris, and Copenhagen. In crossing "esta Europa rasgada por pactos" she worked with the Chilean Ambassador to Berlin and the British consul in Alicante ${ }^{113}$. They tried to evacuate Portuguese citizens from Madrid, an action that Chile's Legation in Spain, strongly pro-Nationalist, apparently contested: “Todos los portugueses que se encontraban en Madrid salvo por acaso emigrados políticos o individuos sujetos a la acción de la justicia tuvieron ocasión de salir desde hace mucho tiempo", they wrote ${ }^{114}$. But Mistral's example apparently inspired some of her colleagues then in Lisbon. Julio Prado had seen where "la situación nacionalista" was headed. He wanted to help in one of two ways: "uno de obtener licencia del Ministerio para ir a Marsella o a Bruselas a ocuparse de la atención de los refugiados españoles y otro de ir a trabajar a Madrid donde sabía que estaba solo el señor Nuñez Morgado". As she reported to her superior in Santiago, she saw no reason not to provide mild but positive encouragement, all the while reminding him to be sure that "sus informes eran del agrado del Ministerio"115. Writing to a Chilean colleague based in the US, she confessed that she wanted to escape the narrow nationalism that underlay Europe's problems: "La Europa se viene imposible [...] Creo en la patria, pero en la patria grande"116. By May of 1937, her reprieve was coming to an end: she and Cosío Villegas and his family all left Lisbon with a group headed for Paris. While he traveled on to the the leftist writer's conference in Valencia, Ema and Gabriela went on to Copenhagen to meet up with Palma Guillén before Gabriela continued on Paris, where she'd spend a lot of June and July ${ }^{117}$.

The news from Barcelona, where Communists and anarchists battled to control the city, splintering the left, signaled the end of idealistic prospects. The

\footnotetext{
112 Idem.

113 Gabriela Mistral, letter to Palma Guillén, about 1936, op cit.

114 Telegram sent to Hedilla, Salamanca, for the Ambassador of Chile in Berlin via Legación de Chile en Portugal, 2 March 1937, Dana Atkinson Archive.

115 Mistral, letter to Carlos Errázuriz Ovalle, op. cit.

116 Gabriela Mistral, letter to Torres Rioseco, April 1937, in Literary and Cultural Journeys: Selected Letters to Arturo Torres-Rioseco, Carlota Caulfield and Miguel Ángel Zapata (eds.), Oakland, Center for the Book, 1995, 126.

117 Alberto Romero, España está un poco mal, Santiago, Ercilla, 1938, 90-93, offers useful details about these encounters between differing sides in the conference of "committed intellectuals" in Valencia in June of 1937. Mistral did not attend this conference because she had already agreed to be at the League of Nations' sponsored conference in Paris, in yet another sign of her difference from the more markedly leftist tendencies of this Valencia-bound group, which included large delegations from Mexico, including her good friends Daniel Cosío Villegas and Carlos Pellicer, and friends of hers from Cuba, with both of these delegations financed by Mexico.
} 
Anarchists were losing, Mistral wrote, because "[...] soñaban con unas comunidades primitivas [...] creyeron que les permitiría ser Arcadia en medio del zafarrancho general"118. Traveling on the boat from Oporto to Cherbourg gave Gabriela Mistral the opportunity to ponder the devastation in the Basque country. “A mí se me cierra el corazón de leer los detalles de la destrucción de esa zona [...] La locura es general, como en los carnavales"119. Contradictory radio reports blared in the hotel lobbies:

“[...] hay días en que se dicen [...] que hay que matar a los extremistas españoles que dividen a los gubernamentales matándolos a todos y dando su cálculo en dos millones (servicio de los rojos) y que hay que reestablecer la Inquisición, para limpiar la fe de la nueva España (servicio de los nacionalistas). Una se pregunta si ha oído de veras o si también se ha vuelto loca $[\ldots . .]^{\prime 120}$.

Leaving Portugal led Mistral to ponder the silences produced by "este trance de la pobre España en desgracia". Necessity imposed some silences: "tenemos que callar". Some people chose silence: "sin deber que los ate, se quieren callar" 121 . Much of what she'd done in Portugal would have to be silenced, as she explained to a friend: “Así se va la vida, medio en trabajar, medio en callarse [...] Dos años han sido los de cura en Portugal. Y no me rehago aún"122. She acknowledged the constraints when she wrote from Paris to Victoria Ocampo: "no tengo boca libre, mano de escribir libre. Algo haré y sin embargo"123. To do nothing would be worst of all: "El fascismo caerá sobre la América verticalmente, si gana en España. Y lleva las de ganar" 124 . She was forthright, however, in a confidential letter to her consular supervisor in Santiago. She'd had enough of the censorship that fascism imposed:

"Yo me estoy cansando de vivir en estos curiosos países de dictadura medieval. Artículos para mis diarios no puedo escribirlos sino sobre asuntos que sean de otro planeta, que no toquen el medio; refugiados españoles que viven pidiendo el oro y al moro también ya me fatigan con sus cien problemas"125.

The poet used allegory to write a final "recado" from Portugal. The land's dense medieval history furnished the background to her "Recado sobre Dos Sepulcros en Alcobaca", which she composed in May of 1937. In this allusive and carefully controlled essay she compared and contrasted the separate yet related destinies of Portugal and Spain ${ }^{126}$. The story tells how Pedro I ("el Justiciero, o el

118 Mistral, letter to Pío Baroja, op. cit., 239-40.

119 Mistral, letter to Carlos Errázuriz Ovalle, op. cit.

120 Idem.

121 Gabriela Mistral, letter to Joaquín García Monge, 10 May 1937, in Gabriela Mistral y Joaquín García Monge: una correspondencia inédita, Magda Arce (ed.) con la colaboración de Eugenio García Carrillo, Santiago, Andrés Bello, 1989, 128-129.

122 Gabriela Mistral, letter to A. Arias, May 1937, in Mistral, Antología Mayor III, op . cit., 267.

123 Gabriela Mistral, letter to Victoria Ocampo, July 1937, in Esta América nuestra, op. cit., 59.

124 Idem.

125 Mistral, letter to Carlos Errázuriz Ovalle, op. cit.

126 Gabriela Mistral, "Recado sobre dos Sepulcros de Alcobaca, Portugal", May 1937, en Recados para hoy y mañana, Luis Vargas Saavedra (ed.), Santiago, Sudamericana, 1999, 77-88. 
cruel") exacted vengeance for the murder of the mistress he passionately loved, Doña Inés, who bore him three children. Pedro and Inés were, she told Pío Baroja, "formidables amantes, esa pareja rebanada por una corte que no pudo tolerar que se amaran"127. Verona's tragic Romeo and Juliet paled by comparison; this machinery of one man's vengeance and the collapse of distinctions between the mortal and supernatural worlds more closely resembled Hamlet in Elsinore, which the poet had recently visited. Despite her story's ending with the macabre coronation of a posthumous queen, Portugal's folklore and common people gave her hope: "tiene una densa y ancha aura poética, no se la quiebra aún por el industrialismo [...] El repertorio de los fantasma dulces o violentos, resulta formidable"128. The combination reminded her of Mexico: "Don Dionisio o Diniz como lo dice la dulce lengua portuguesa [...] es un Quetzalcoátl aparecido en Portugal para refrenarle al clero y la nobleza"129. She contrasted "el furor hereditario" of Castilla, "una marmita de guerras familiares" with "la masa portuguesa [...] humanísima y también tierna" en "su cristianismo medieval"130.

\section{PARis, Río: June- August 1937: “[...] LA He Vivido Desde Portugal. Será COSA DE CONTÁRSELA EN DÍAS Y NOCHES"}

In June of 1937, the news kiosks of Paris displayed photos and headlines of the 500 Spanish children who'd arrived in México. Leftist President Lázaro Cárdenas had his picture taken with them all. Critics on the right could hardly complain as their government basked in the Republican cause. Who could object to rescuing children? Did it now matter, in Mexico, whether their parents, many of them now missing or deceased, had been Nationalists, Republicans, or Monarchists? Palma Guillén, as it turns out, would be deeply involved in the post-Civil War negotiations over the fate of these children. In the meantime, Mistral tied this symbolically important event -the arrival of Spanish children to Mexico- with her invitations into the Republic of Letters. In a letter to Victoria Ocampo, Mistral made a direct and unvarnished proposal: SUR should publish the poet's new book. "Así, brutalmente, se lo propongo, antes de salir de París". She apologized for

"esta petición escueta y que parece pretenciosa. Hay en su abuso más deseo que el de hacer alguna cosa válida por esas criaturas de media sangre nuestra. Según Victoria Kent, alrededor de 200.000 niños (¡nada menos!) han salido de España. Mejor es, Dios Santo, que queden allá adentro con los suyos. Nuestra América ciega de fanatismo político se ha cruzado de brazos. Excepto México, que ha aceptado 600 y va a recibir más $[\ldots] " 131$.

127 Mistral, letter to Pío Baroja, op. cit., 240.

128 Mistral, "Recado sobre dos Sepulcros", op. cit., 78.

129 Ibid., 78-79.

130 Ibid., 84-85.

131 Gabriela Mistral, letter to Victoria Ocampo, 4 Aug. 1937, in Esta América nuestra, op. cit., 61-62. 
Ocampo's response greeted Mistral's arrival in Río. Ocampo protested that the poet's proposal -to let Sur publish Tala- contained "cosas que se reconoce como de Gabriela y otras que no son de ella"132.

“De quién, entonces?”, Mistral queried. "Mi cara seca y dura me libró siempre de mandones o consejeras. Mía es esa carta, entera mía. Déme Ud. por ella lo que me merezca, pero no la tenga por soplada [...]"133. Gabriela Mistral reminded her friend of how she'd made the rounds of Parisian hotels and cafes, all the while defending Ocampo from numerous political slanders. She talked with Bergamín, with Maritain, with Duhamel. She'd learned more about Spain, but she'd only talk about it when they saw one another face to face. "Lo de España se me ve [tatuado] estampado en la cara [...] Será cosa de contársela en días y noches [...]"134.

Ocampo decided to publish Tala for free, with the sales donated to help Basque war orphans. Mistral commenced to defend and promote Ocampo's interests in SUR magazine and press in the astonishing, eighteen month, eight country tour that she'd already launched from Portugal to Paris, and Paris to Río, where the poet had already made her first radio address in Brazil, speaking of schools and Mexico's leadership. With characteristic irony and affection she wrote to Alfonso Reyes from a Rio cafe at the end of the August 1937: thanks to "la bella censura portuguesa [...] Aprendí a hablar en puras abreviaturas". Silence remained crucial, as she related how the capture of "Fernández", a Spaniard, had led to the capture of "las otras buenas personas portuguesas" who'd helped him: "todas ellas presas por su culpa"135. Yet the poet doubted that life in Brazil, or anyplace, would be free of "un policía en la esquina y dos o tres espías adentro del hotel"136.

After six months in Brazil and a month in Montevideo, the poet went on to Argentina before entering Chile. She alternated between events with the requisite throngs of schoolchildren, tense meetings with intellectuals, and fleeing into the homes of friends. Her presence provided Chile's media with diversion from covering the seething Presidential campaign. In Santiago, she attended intimate teas for a hundred, briefings in the Ministerio de Relaciones Exteriores, and at least two late-night tête-à-têtes with Delia and Neruda, who apparently didn't mention that his father had just died in Temuco twelve days earlier.

From Chile, the poet -accompanied by Coni- visited Peru, where they met with the poet's friends in the opposition. Her ship had left Ecuador when she got the news of Pedro Aguirre Cerda's victory at the head of the Popular Front. As Dr. Eduardo Santos, her other friend and patron, had won the Colombian Presidency in that same year, Gabriela Mistral's future now appeared curiously open. The success of her American tour posed a puzzle to Chile's new President. How to make use of her? Before the election, she'd declined consulate offers in Argentina and Brazil. After the election, she declined to serve as Minister Plenipotentiary to

\footnotetext{
132 Gabriela Mistral, letter to Victoria Ocampo, 31 Aug. 1937, in ibid., 62.

133 Idem.

134 Ibid., 65

135 Gabriela Mistral, letter to Alfonso Reyes, 21 Aug. 1937, in Tan de Usted, op. cit., 112.

136 Mistral, letter to Victoria Ocampo, 31 Aug. 1937, op. cit., 66.
} 
Central America, effectively an Ambassadorship. Writing to Victoria Ocampo, the poet explained her simple request -a consulate in Nice, France- by invoking politics, family, and her network of friends: "No me quedan sino dos países no fascistas en el mundo, mi Votoya: esta gringuería y aquello [...] Me voy también por estar cerca de Palma. Es mi única familia en este mundo [...] Y me voy también porque allá puedo ocuparme de la Coop. Int. a lo menos"137.

\title{
EPILOGUE: NeW YoRK AND FRANCE, APRIL-JUly, 1939
}

Bombers flew overhead. French officials distributed sandbags. Mistral and Coni roamed Nice, looking for a pension or rented rooms that could double as a bomb shelter. She went to Cannes to celebrate her fiftieth birthday with Victoria Ocampo and Ocampo's latest amour, Roger Caillois.

Reyes also celebrated his fiftieth birthday. An intrigue produced his recall from Buenos Aires to Mexico City. With his twenty years of diplomatic service at an end, the writer was philosophical: "Estoy en la edad en que los hombres de otros siglos lo dejaban todo para irse a Jerusalén, ellos creían que por impulso místico y, en rigor, más bien para huir de los automatismos creados por la vida habitual"138.

Daniel Cosío Villegas sent Gabriela Mistral an update on the results of their joint efforts from Portugal.

\begin{abstract}
"Recordará usted que el punto mejor y más fuerte de la lista primitiva lo componían los principales Miembros del Centro de Estudios Históricos: Menéndez Pidal, Dámaso Alonso, Fernández Montesinos, Navarro Tomás, y Sánchez Albornoz. A ninguno de ellos conseguimos: don Ramón renunció pronto a venir tanto por temor a la altura, como por tener parte de su familia en campo franquista y al parecer sin medio de sacarla; Dámaso se excusó en un principio por motivos de salud, ante nuestra insistencia decidió al fin aceptar la invitación, pero era tarde para entonces: en los días mismos en que caía Barcelona; Fernández Montesinos, pudo haber aceptado venir, pero ciertas razones de índole personal, que no podíamos modificar, se lo han impedido hasta ahora [...] entre ellas esta ya María Zambrano, quien trabaja en la Universidad de Morelia”.
\end{abstract}

Daniel Cosío Villegas worked so that Reyes would be appointed to serve as president of "La Casa de España en México", which now consisted of thirty resident and ten associate members ${ }^{139}$.

Tomás Navarro Tomás had stayed in Madrid, managing the preservation of libraries and artworks during the aerial bombing. He hadn't left for France until January of 1939. Writing to Mistral from New York, he listed the professors, writers, and artists who were passing through and gathering, bit by bit, in Mexico:

137 Gabriela Mistral, letter to Victoria Ocampo, early Feb. 1939, in Esta América nuestra, op. cit., 100 .

138 Alfonso Reyes, letter to Gabriela Mistral, July-Aug.? 1939, in Tan de Usted, op. cit., 120.

139 Daniel Cosío Villegas, letter to Gabriela Mistral, 4 May 1939, Gabriela Mistral Collection, Library of Congress microfilms. Filed under "Reyes, Alfonso". 
the ophthalmologist Dr. Marquez, the astronomer Dr. Pedro Carrasco, the physiologist Dr. Bejarano, the economist Sacristan, the writers Jose Carner, Jose Bergamín, Herrera Petere and Emilio Prados, the painter Jose Renau and the architect Fernandez Callencia. Two more people that Mistral helped came along with their wives: Eugenio Imáz and Enrique and Teresa Diez-Canedo. Since many exiles stayed in France with variable and uncertain addresses, Navarro Tomás saw communication as the chief obstacle "in the effort to maintain spiritual unity" 140 .

In Cossío Villegas's list of evacuees, which centered on the candidates' academic affiliations, and in Tomás Navarro Tomás's list of people who might seek to maintain the "spiritual unity" of Spain, the majority of people who were close friends of Mistral's were liberal Catholic intellectuals (such as Bergamín), Basques (such as Imáz and Zambrano), or Catalans (such as Carner, and later Xirau).

The experience in Mexico and elsewhere would lead to further splintering of identities, whether regional, political, spiritual, or all three. The Catalan writer Marta Pessarradona puts it well: "Qui cregui que la gent de l'exili era una comunitat amorosa i ben avinguda, va errat"141. Ever the outsider, Juan Ramón Jiménez relocated with his wife, Zenobia Camprubí, to Puerto Rico. Among the tiny minority that returned to Spain was María de Maeztu, the very woman who'd started the chain that led to the publication of Tala when she'd brought Victoria Ocampo to Mistral's house in Madrid on a cold January morning five years before. As Mistral sadly foretold, María de Maeztu became an enthusiastic supporter of the fascist state. As Mistral cast her lot with the anti-Franco forces, where the women that were her closest friends were located, she and María de Maeztu never spoke to one another again.

Gabriela Mistral made good her promise to donate the earnings from Tala to institutions helping refugee children from Spain. The funds that Mistral sent to Victoria Kent, which equaled a third of the Chilean consul's annual 1939 salary, went not just to Basque or Catalan orphans, but to child care centers for Spanish refugee children in Paris. Victoria Kent was scrupulous, sending receipts. A more ardent Republican couldn't be found: Kent also returned the passport that the Chilean consul sent her, which gave Victoria Kent permission to enter Mexico as a political exile. Kent rejected the term "exile”. “Por qué tiene miedo de la palabra "emigrante'?" she asked Mistral. "Emigrante político es el título más honorable que podría lucir" 142 . From Nice, Mistral continued to send money, 1500 francs that helped still more Catalans from the University of Barcelona, Ramón and Joaquín Xirau, leave France and travel to Mexico, where they both got jobs teaching in the University ${ }^{143}$.

140 Tomás Navarro, letter to Gabriela Mistral, 11 June 1939, Gabriela Mistral Collection, Library of Congress microfilms.

141 Marta Pessarrodona, "Lluís Nicolau d'Olwer: una incógnita catalana", in Via. Valores, Ideas, Actitudes 4, Barcelona, 2007, 72.

142 Victoria Kent, letter to Gabriela Mistral, 20 July 1939, Gabriela Mistral Collection, Library of Congress microfilms.

143 Joaquin Xirau, letters to Gabriela Mistral, 18 July 1939, 18 March 1940, Gabriela Mistral Collection, Library of Congress microfilms. 
The German invasion drove Kent and other Spaniards underground until the war's end, when Kent left France for Mexico and then the United States. Palma Guillén moved to Geneva to work in the League of Nations and on a relief committee for Republicans. Luis Nicolau survived repeated jailing in France, until he made his way to Mexico, where he joined Cosío Villegas in turning the "Casa de España" into "El Colegio de México", a permanent Mexican institution"144. In Chile, Aguirre Cerda summoned Carlos Errázuriz, the poet's closest colleague in the Ministry of Foreign Relations, and sent him to Stockholm, where he was to work with Gabriela Mistral's translator, a member of the Swedish Academy, "explicándole los matices del vocabulario criollo"145.

\section{CONCLUSIONS}

Gabriela Mistral's relocation to Portugal and her work from Lisbon on behalf of wartime refugees showed that she was politically astute and well-situated among the majority of her friends, liberal intellectuals who regarded the war in Spain not as a conflict between communists and fascists, but as a battle between Spaniards that decimated the Basque country and sent Cataluña's leaders into exile. Mistral's writings from Portugal also show that she came to a deeper understanding of Latin America's marginalization with respect to Europe, by way of Portugal's analogous situation: "[...] Palpo allí las mordeduras de una saudade que me hizo sangrar la memoria, despertando en mí una sensación corporal de lo que es América y cuán América se es, aun más estando lejos de ella"146. Living in proximity to the war in Spain reinforced Mistral's skepticism with regard to nationalist claims. The experience increased her awareness of the fragility of national borders, which she later described as "[...] solo una rayita azul o roja [...] en un mapa de mentirijilla"147.

Mistral's assistance to emigrants and refugees from Spain predated the efforts of other "committed" intellectuals, such as Neruda, whose delay to help signaled his personal and ideological priorities. Like others who eventually aligned with the Communists, Neruda believed in the war within the larger framework of a struggle for the rights of workers and thus, worth fighting to the end. Mistral, by contrast, regarded Spain's splintered left as one tending towards the absolute chaos in which the fascists could well prevail, not just in Europe, but in Latin America. In the meantime, she found a green world of refuge in Portugal, close to Spain's agonies, yet distant enough. "Los años en Portugal fueron para mí una mixtura de Calvario y Arcadia", she told a Basque friend, "toda suntuosidad botánica nos recuerda el Paraíso mal aprovechado [...]"148. Ironically, the election of Pedro Aguirre Cerda

144 Pessarrodona, op cit.; Ross, op . cit., 91-103.

145 Vuestra Gabriela, op. cit. 13.

146 Mistral, letter to Pío Baroja, op. cit., 239-240.

147 Gabriela Mistral, letter to P. Zuloaga y Sanz, 2 Jan. 1947, in Mistral, Antología Mayor III, op. cit., 413.

148 Idem. 
to Chile's Presidency in 1938 once again put Chile in an oppositional stance vis-avis Spain, which now was Nationalist while Chile had the only elected Popular Front government that remained.

In all, Portugal revived Gabriela Mistral, particularly in offering a wider advantage of the Americas, yet the poet-consul was in no way prepared for the complexities of race, colonization and immigration that she'd face in Brazil. 